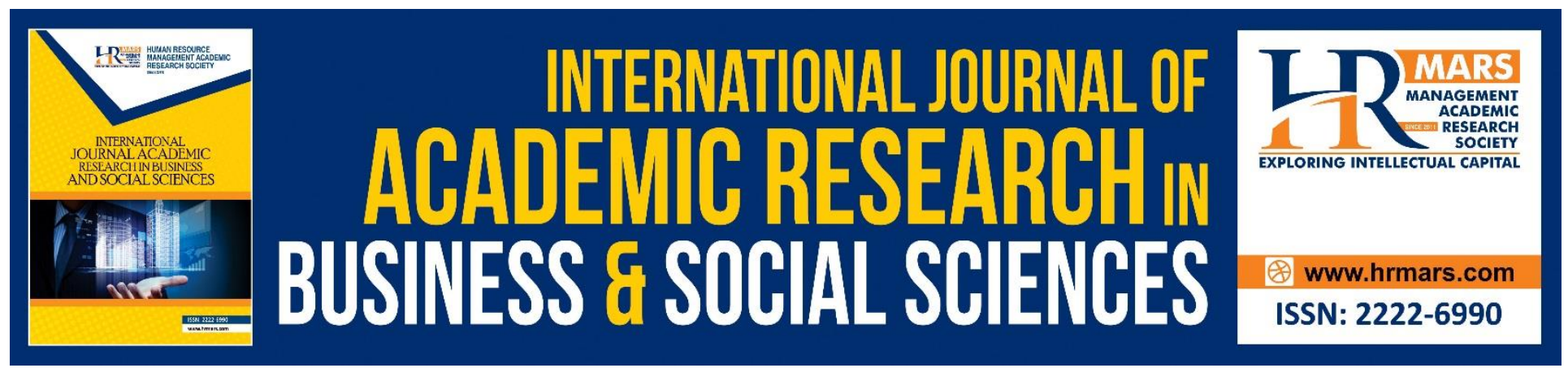

\title{
Technology and HR Practices in Educational Sector in Sharqiya Governate of Oman
}

Najeeb AI Qalhati, Asif Mahbub Karim, Bader Al Mughairi, Khalid Al Hilali, Mohammad Imtiaz Hossain

To Link this Article: http://dx.doi.org/10.6007/IJARBSS/v10-i10/7956 DOI:10.6007/IJARBSS/v10-i10/7956

Received: 02 August 2020, Revised: 26 August 2020, Accepted: 14 September 2020

Published Online: 09 October 2020

In-Text Citation: (Al Qalhati, et al., 2020)

To Cite this Article: Al Qalhati, N., Karim, A. M., Al Mughairi, B., Al Hilali, K., \& Hossain, M. I. (2020). Technology and HR Practices in Educational Sector in Sharqiya Governate of Oman. International Journal of Academic Research in Business and Social Sciences. 10(10), 435-443.

Copyright: (c) 2020 The Author(s)

Published by Human Resource Management Academic Research Society (www.hrmars.com)

This article is published under the Creative Commons Attribution (CC BY 4.0) license. Anyone may reproduce, distribute, translate and create derivative works of this article (for both commercial and non-commercial purposes), subject to full attribution to the original publication and authors. The full terms of this license may be seen at: http://creativecommons.org/licences/by/4.0/legalcode

Vol. 10, No. 10, 2020, Pg. 435 - 443

http://hrmars.com/index.php/pages/detail/IJARBSS

JOURNAL HOMEPAGE

Full Terms \& Conditions of access and use can be found at http://hrmars.com/index.php/pages/detail/publication-ethics 


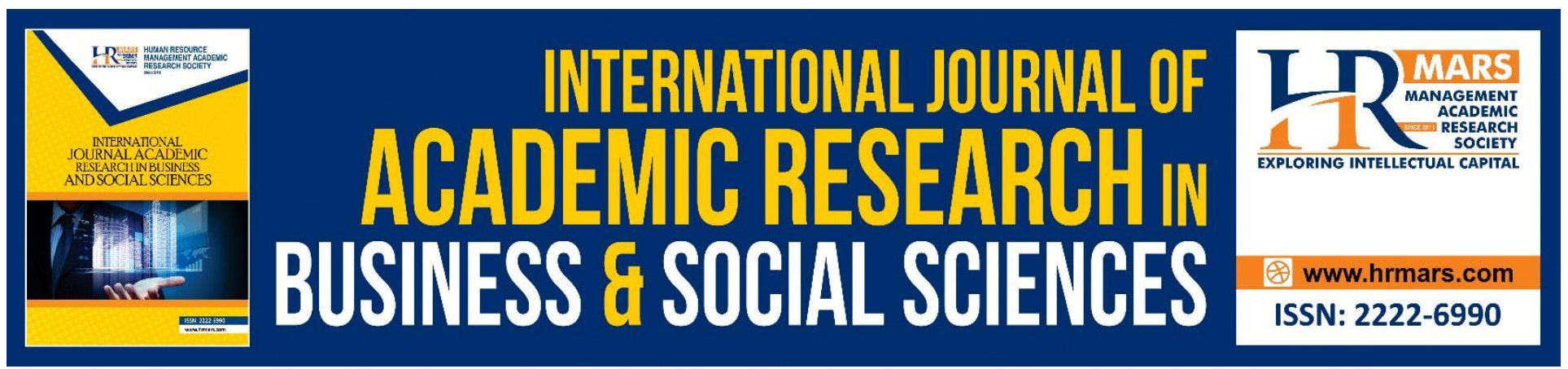

\title{
Technology and HR Practices in Educational Sector in Sharqiya Governate of Oman
}

\author{
${ }^{1}$ Najeeb Al Qalhati, ${ }^{2}$ Dr. Asif Mahbub Karim, ${ }^{3}$ Bader Al Mughairi, \\ ${ }^{4}$ Khalid Al Hilali, ${ }^{5}$ Mohammad Imtiaz Hossain \\ $1,3,4 \mathrm{PhD}$, Research Fellow, Binary University, Malaysia, ${ }^{2}$ Associate Professor and Dean, Binary \\ Graduate School, Binary University, ${ }^{5}$ Postgraduate Student, Universiti Putra Malaysia
}

\begin{abstract}
Technology has a massive impact on the human resource practices executed by managers at different organizations. The emergence of technological advancements ranging from gadgets, software, and Internet of Things has reshaped the operations of human resource department. At a broader perspective, technology has impacted the manner on which organizations execute their operations globally. The educational sector of Sharqiya Governorate has encountered massive development in communication segment relative to the operation of human resource practices. The assessment of goals and objective of an organization can be forecasted by evaluating various categories of data such as work ratings and job completion of ratings of workers.
\end{abstract}

Keywords: Education Sector, Technology, Employees Performance.

\section{Introduction}

Technology has a massive impact on the human resource practices executed by managers at different organizations (Ong et al., 2020; Hossain et al., 2020). The emergence of technological advancements ranging from gadgets, software, and Internet of Things (IOT) has reshaped the operations of human resource department. (Alshams et al., 2020) stressed on the use of information technology as it has been an absolute requirement for increasing the efficiency of public administration and management development. The studies of Ferraris et al. (2018) outlined that technology has influenced the manner in which the human resource departments link with employees, record files, and assess the performance of workers. Proper utilization of technology at workplace enhances the operating efficiency as well as the effectiveness. In a broader context, implementing information technology strategically is very crucial for achieving country's goals (Alshamsi, Hock, Karim, \& Hossain, 2019). On the contrary, inappropriate utilization of technology at workplace affects the management of human resources within an organization negatively. The general overview of employees within an organization can be obtained after gathering and examining data using technological tools. 
INTERNATIONAL JOURNAL OF ACADEMIC RESEARCH IN BUSINESS AND SOCIAL SCIENCES Vol. 10, No. 10, 2020, E-ISSN: 2222-6990 @ 2020 HRMARS

\section{Technology and HR Practices in Educational Sector}

At a broader perspective, technology has impacted the manner on which organizations execute their operations globally. In order to respond positively to the ever-changing demand and preferences of consumers, organizations have applied technological concepts to offer reliable solutions (Bhadoriya, Bajpai and Patwardhan, 2017).

Technology has facilitated the shift of HR practices from the traditional administration of employees to a strategic management of organizational workers. Through the use of modern human resource management technological practices, organizations have been capable of realizing competitive compensation, the engagement of employees and effective strategies of retaining talent (Marler and Parry, 2016). The recruitment and training operations of an organization are currently executed using the internet. Following the acquisition of the workers in different employment position, communication and assessment of their performance is performed using technological instruments as well (Ulrich and Grochowski, 2018).

The adoption and utilization of technology in HR practices has affected the educational sector. HRM departments in different organizations are able to apply decisions that are formulated after a thorough and careful consideration (Lyskova, 2016). The technology has played a critical function in the transformation process of human resource professional practices.

There are various ways in which the current technology has reshaped the practices of Human Resources in the educational segment and they include the following.

\section{Facilitating Easy Communication}

At an organizational setting, communication is considered a crucial factor that must be integrated in day to day running and facilitate smooth running. Establishing effectual communication is significant in enhancing positive relationship among individuals. The millennial generation has facilitated the advancement of communication from verbal to non-verbal especially with the current utilization of technology. The educational sector of Sharqiya Governorate has encountered massive development in communication segment relative to the operation of human resource practices. For instance, the communication between the management and the employees has been improved due to effectual communication.

With the emergence of technological mobile texts, emails and other messaging applications, human resources at the educational sector are capable of linking with other employees within the company. The human resource manager can share information and attachments with a broad number of recipients at the same time without necessary linking with each member individually (Mao et al., 2016). The process implies that the process taken to execute human resource organizational decisions is less with the application of technology compared to the failure to use technology. Moreover, communicating a scheduled meeting with a large number of employees can be performed using a single email that will be distributed to hundreds of employees within the organization. Technology has enabled the human resource departments in the educational sector to communicate the most crucial information to the organization (Johnson, Lukaszewski and Stone, 2016).

\section{Efficient Handling of Large Amount of Data}

In the current world, organizations rely heavily on information to perform their daily responsibilities. The ability to rely on such information has facilitated the gathering and analysis of large amounts of data (Guo et al., 2010). Generally, the organization collects large amounts of data in order to enhance 
INTERNATIONAL JOURNAL OF ACADEMIC RESEARCH IN BUSINESS AND SOCIAL SCIENCES Vol. 10, No. 10, 2020, E-ISSN: 2222-6990 @ 2020 HRMARS

the adoption of both operational and strategic decisions. The decision-making process of an organization will depend on the data provided by the HR department related to the effectiveness of human resources.

The human resource management gathers and assesses data related to employee performance. The assessment of such data can take multiple forms depending with needs and expectations of an organization on such data. For clarification, the HR department in educational sector might be interested in assessing the performance of employees through the use of analytical instruments such as analysis software. Effective Human Resource practices should be capable of determining the volume of data that can obtained as well as how the data should be collected. The application of technology prevents the incident whereby the data collected is large compared to what HR specialists can handle (Gunasekaran et al., 2017). With effective management of large data, the organization can achieve its long-term objectives relative to the human resources.

\section{Assessment of Employee Performance Data}

The use of technology in the HR practices has redesigned how HR departments execute different duties in the educational field of South Sharqiya Governorate in Oman. The data related to employee names, salaries, age, allowances, and their respective responsibilities can be efficiently analyzed using technological tools and software. The research studies of Cheon et al. (2012) suggested that the use of technological concepts in human resource management is a critical option that has revolutionized the operation and handling of human capital by global organizations. The assessment of goals and objective of an organization can be forecasted by evaluating various categories of data such as work ratings and job completion of ratings of workers.

Since human capital forms the basis and success of educational sectors, the assessment of employee performance using technological tools has a huge impact on the base line. Employees in educational sector tend to perceive appraisal as a process that will lead to overall improvement of their productivity and working knowledge. In circumstances when the employees are not satisfied with customers, technological instruments will rate the morale of workers, hence, identifying such weaknesses. Technology is more effective for assessment of employee performance since it establishes a high-working culture while encouraging the top performing employees within an educational sector. The assessment of employees in an educational sector enables the organization to recognize knowledge gaps, build up development programs, learning programs, maintain workers and formulate an effective strategic plan for the organization.

The elimination of outdated HR practices related to employee performance is a relevant move that paves a way for the incorporation of technological practices. Since South Sharqiya educational sector has multiple employees, the incorporation of technological HR practices will record the real time operation of workers, hence, providing advanced solution to the probable challenges and problems. The research findings of Cascio and Boudreau (2016) outlined that HR managers encounter flexible operations when they perform using technological concepts.

\section{Technology Has Reshaped Employee Recruitment Process}

Before the development of internet, the recruitment of employees by the human resource department relied heavily on face to face means. The technological advancement in the $21^{\text {st }}$ century has enabled organizations to advertise prospective job opportunities online. Moreover, the recruitment of employees in those organizations has been conducted online through different 
INTERNATIONAL JOURNAL OF ACADEMIC RESEARCH IN BUSINESS AND SOCIAL SCIENCES Vol. 10, No. 10, 2020, E-ISSN: 2222-6990 @ 2020 HRMARS

technological means of communication such as telephone, internet and emails. In the current world, more time has been saved, especially with the elimination of long-lasting face to face interviews and assessment of paper resumes.

With the emergence and development of social media platforms such as Facebook, Twitter, Linkedln and Snapchat, the identification of candidates, recruitment and retention of employees has been completed online. Recruitment is considered among the most significant roles of human resource department (Holm and Haahr, 2018). As a result of the use of online portals in the educational sector of South Sharqiya, the recruitment process of employees has been taken to the next level with human resource managers targeting specific experts in respective educational segments.

The studies of Al Wahshi (2016) revealed that the emergence of technology in the recruitment process of South Sharqiya educational sector has been enhanced by the introduction of cloud-based recruitment software. Nevertheless, the HR department has launched Application Tracking System (ATS) to offer a smooth recruitment process. The application has offered relevant features that play a critical segment in overcoming challenges while attaining significant recruitment objectives. Additionally, the educational sector has used video and Skype interviewing instruments to recruit human resources.

\section{Enhancing the Security of Employee-Related Information}

During the early days, securing employee data and records simply meant storing such information in safe cabinets. As a consequence of technological revolution, the security of employee information has been advanced to the next level. The most effectual human resource practices must constitute the protection of employee data that form a vital part of personal privacy. For elaboration, a good firewall is considered relevant in an attempt to reduce possible information leakage to third parties and hackers (Ramalingam, Khan and Mohammed, 2016).

As part of human resource practices in the educational sector, the HRM must include effective policies and regulations that will management of human-related data stored in cloud and internal servers as a softcopy. The confidentiality of data in HR departments cannot be performed without including technology. The educational sector in South Sharqiya, Oman has applied cloud computing to support data decentralization and storage. The use of technology has led to the elimination of the traditional physical server storage systems, which are considered as ineffective. The use of technology has enabled HR managers to access organizational data through a decentralized cloud computing system. Moreover, some departments of the educational sector of South Sharqiya have adopted the use of a web-centered content management system.

In order to provide a comprehensive analysis of how technology has remodeled the practices of human resource department in the educational sector of South Sharqiya, Oman, the emerging issues and trends related to the technological human resource management will be re-evaluated.

\section{Current Technological Trends Related to Human Management The Future of Mobile Applications}

The emergence of iPhones and smartphones has taken over the world of human resources. The HR managers are more focused with providing a business environment whereby employees enjoy the use of mobile applications as well as software programs designed for mobile phones. The educational sector has designed customized applications that enable workers to have personal working profile based on their real working data. Since the current technological world is rapidly transforming, HR 
INTERNATIONAL JOURNAL OF ACADEMIC RESEARCH IN BUSINESS AND SOCIAL SCIENCES Vol. 10, No. 10, 2020, E-ISSN: 2222-6990 @ 2020 HRMARS

departments have moved in alignment with these transformations by incorporating the use of mobile applications as part of their operations.

In order to deliver services that are consistent with the current technological trend, HR practice in the educational sector of South Sharqiya will consider designing applications fitted with mobilization system and the type of working interface sought by employees. The requirement to design these applications has been triggered by the evolvement of HR basic functionality requirements. The research studies of Gheisari and Irizarry (2016) outlined that the utilization of mobile applications in the current world has become essential for different websites and systems designed by an organization.

\section{The Use of SaaS and Cloud Technology}

In the current technologically evolving world, SaaS apps are considered to as crucial in the practices of human resource department. Based on the nature and rapid transformation of the business environment, cloud centered applications are inevitable way of operation. Until the emergence of the cloud computing, the storage and gathering of data has been made easier. The employment data, operation data as well as the data related to compensation structure of employees can be assessed more easily. The educational sector of South Sharqiya will utilize the concepts of SaaS apps and cloud technology to organize data more securely (Al Musawi et al., 2016).

Before utilizing cloud computing fully, the education sector of South Sharqiya will have to assess its internal working structure and determine whether the objectives align with current needs of the department (Tawafak et al., 2018). For a successful assessment, HR manager must compare challenges of various human resource practices with the benefits obtained after the application of cloud computing tool. Additionally, the human resource manager will reconsider whether all educational procedures of South Sharqiya can shift the technology and applications. A sense of belonging amongst workers will be established when data of the entire educational sector will be decentralized in cloud.

\section{The Trend of Huge Data Powering Organizations}

One of the key objectives of HR departments is to promote the compliance and safeguard the organization against any risk associated with human resources (Al Mahrami and Hakro, 2018). The establishment of HR digital platforms has enabled the educational sector of South Sharqiya to digitize information, hence promoting effective and effectual handling of such information. The capability of gathering and analyzing huge amounts of data has enabled the organization to have a comprehensive understanding of their workers. The objective has been achieved through the usage of employee assessment software at workplace (Saxena, Kumar and Sharma, 2016).

Upon integration with other crucial technologies, the big data has enabled human resource departments to gain considerable insight knowledge. The understanding gained facilitates effective decision-making through utilization of vital organizational information. At an educational sector setting, the emerging trend of big data will enable human resource departments to obtain a detailcentered overview of the current labor structure to permit them to recognize any rising trends (Paul et al., 2016). According to the research studies of Akter et al., (2016), big data supports the general operations of an entire organization and not just the human resource department. 
INTERNATIONAL JOURNAL OF ACADEMIC RESEARCH IN BUSINESS AND SOCIAL SCIENCES Vol. 10, No. 10, 2020, E-ISSN: 2222-6990 @ 2020 HRMARS

\section{The Shift to Wearable Technology}

Wearable technology is considered essential in inter-connecting employees and saving time. The trend has been implemented by different countries across the globe including Microsoft and Google (Tarhini et al., 2017). Given than time management is a vital factor in the management of human resources, wearable technology will transform the educational sector of South Sharqiya in Oman (Emam, 2016). Wearable technology facilitates the provision of incentives to employees that will later enhance operating efficiency. To align with the ever-transforming technology, the human resource department will explore more useful approaches that will change wearable technology into useful human resource tools.

\section{The Trend of Social Media as an Influential Instrument}

The establishment of social media has played a critical function in human resource departments today. The findings of Lanier (2017) revealed that during the next 10 years, human resource managers will be executing job interviews through social media platforms. At the educational sector of South Sharqiya, HR managers are using Facebook and LinkedIn to recruit employees. The department has been able to utilize these tools for enhancing the engagement of workers in business.

Through the integration of relevant company profile information, the HR department can access prospective employees through the wide-network of social media. Social media is considered the major source where organizations can attain achieve their human resource objectives. Employees can list their job applications accompanied by their personal information in different social medial platforms. The subsequent step involves waiting for the human resource departments to contact them for interview using the same medium. Additionally, social media platforms have provided useful information relative to ideas of job seekers concerning the educational sector of South Sharqiya. Nevertheless, the information has been significant in formulating effectual payment structures and systems in alignment with expectations of human resources.

The human resource professionals will obtain multiple advantages from the use of social media instruments including assessing the current news and technological advancements. The sharing of industry knowledge between human resource professionals and prospective job seekers has contributed towards enhanced relationship. As a result, the trend of technological social media platform has been considered as crucial engagement tools. Better employee-HR department relationship will improve communication in the workplace.

While the emergence and development of technology has played a critical duty of transforming the practices of human resource professionals in the educational sector of South Sharqiya, HR managers have the responsibility of maximizing the use of this technology in order to reap more benefits to the business community. Technology is constantly re-shaping the future of human resource operations especially with the establishment of educational online portals. The HR department is mainly concerned with recruiting prospective workers, human management and implementing procedures necessary for enhancing the production of human resources. As the dynamics in technology continues to redesign the segment of human resources, businesses will become smarter due to the employment of skillful and knowledgeable human resources.

\section{Corresponding Author}

Prof. Dr. Asif Mahbub Karim

Dean , Binary Graduate School 
INTERNATIONAL JOURNAL OF ACADEMIC RESEARCH IN BUSINESS AND SOCIAL SCIENCES

Vol. 10, No. 10, 2020, E-ISSN: 2222-6990 @ 2020 HRMARS

Binary University, Malaysia

+60172234854

Email: drasifmkarim@gmail.com

\section{References}

Akter, S., Wamba, S. F., Gunasekaran, A., Dubey, R., and Childe, S. J. (2016). How to improve firm performance using big data analytics capability and business strategy alignment?. International Journal of Production Economics, 182, 113-131.

Al Mahrami, E. H. K., and Hakro, A. N. (2018), March. Effectiveness of ERP system in selected organizations in Sultanate of Oman. In 2018 Majan International Conference (MIC) , 1-6. IEEE.

Alshams, Y. A. A. B., Adaikalam, J., Karim, A. M., Hock, O. Y., \& Hossain, M. I. (2020). Application of Strategic Management Information System (SMIS) in the Ministry of Interior, UAE: Issues and Challenges. International Journal of Academic Research in Business and Social Sciences, 10(2), 346-361.

Alshamsi, Y. A. A. B., Hock, O. Y., Karim, A. M., \& Hossain, M. I. (2019). Developing a Framework on Performance and Challenges of Strategic Management Information System: A Case study on Ministry of Interior, UAE. International Journal of Academic Research in Business and Social Sciences, 9(5), $633-646$.

Al Musawi, A., Al Hashmi, A., Kazem, A. M., Al Busaidi, F., and Al Khaifi, S. (2016). Perceptions of Arabic language teachers toward their use of technology at the Omani basic education schools. Education and Information Technologies, 21(1), 5-18.

Al Wahshi, A. S. (2016). Human resource planning practices in the Omani Public Sector: An exploratory study in the Ministry of Education in the Sultanate of Oman.

Al-Jahwari, M., and Budhwar, P. S. (2016). Human resource management in Oman. In Handbook of human resource management in the Middle East. Edward Elgar Publishing.

Bhadoriya, M. C., Bajpai, N., \& Patwardhan, M. (2017). Identifying and prioritizing the determinants of e-HRM: an AHP approach. Annual International Conference on Enterprise Marketing \& Globalization, 17(8).

Cascio, W. F., and Boudreau, J. W. (2016). The search for global competence: From international HR to talent management. Journal of World Business, 51(1), 103-114.

Cheon, J., Lee, S., Crooks, S. M., and Song, J. (2012). An investigation of mobile learning readiness in higher education based on the theory of planned behavior. Computers \& education, 59(3), 1054-1064.

Emam, M. (2016). Management of inclusive education in Oman: A framework for Action. Support for Learning, 31(4), 296-312.

Ferraris, A., Santoro, G., Bresciani, S., and Carayannis, E. G. (2018). HR practices for explorative and exploitative alliances in smart cities: evidences from smart city managers' perspective. Management Decision, 56(6), 1183-1197.

Gheisari, M., and Irizarry, J. (2016). Investigating human and technological requirements for successful implementation of a BIM-based mobile augmented reality environment in facility management practices. Facilities, 34(1/2), 69-84. 
INTERNATIONAL JOURNAL OF ACADEMIC RESEARCH IN BUSINESS AND SOCIAL SCIENCES Vol. 10, No. 10, 2020, E-ISSN: 2222-6990 @ 2020 HRMARS

Gunasekaran, A., Papadopoulos, T., Dubey, R., Wamba, S. F., Childe, S. J., Hazen, B., and Akter, S. (2017). Big data and predictive analytics for supply chain and organizational performance. Journal of Business Research, 70, 308-317.

Guo, S., Degiere, C. M., Kumar, A., Lai, A. C., and Li, X., Microsoft Technology Licensing LLC, (2019). Organizational data enrichment. U.S. Patent Application 10/242,258.

Holm, A. B., and Haahr, L. (2018). E-recruitment and Selection. In e-HRM , 172-195. Routledge.

Hossain, M. I., San, O. T., Ling, S. M., Said, R. M. (2020). The Role of Environmental Awareness and Green Technological Usage to Foster Sustainable Green Practices in Bangladeshi Manufacturing SMEs. International Journal of Advanced Science and Technology, 29 (7s), 3115-3124

Johnson, R. D., Lukaszewski, K. M., and Stone, D. L. (2016). The evolution of the field of human resource information systems: Co-evolution of technology and HR processes. Communications of the Association for Information Systems, 38(1), 28.

Lanier, K. (2017). 5 things HR professionals need to know about generation Z: Thought leaders share their views on the HR profession and its direction for the future. Strategic HR Review, 16(6), 288-290.

Lyskova, I. (2016), August. Moral concepts of modern business processes. In International Conference on Judicial, Administrative and Humanitarian Problems of State Structures and Economical Subjects (JAHP 2016). Atlantis Press.

Mao, H., Liu, S., Zhang, J., and Deng, Z. (2016). Information technology resource, knowledge management capability, and competitive advantage: The moderating role of resource commitment. International Journal of Information Management, 36(6), 1062-1074.

Marler, J. H., and Parry, E. (2016). Human resource management, strategic involvement and e-HRM technology. The International Journal of Human Resource Management, 27(19), 2233-2253.

Paul, A., Ahmad, A., Rathore, M. M., and Jabbar, S. (2016). Smartbuddy: defining human behaviors using big data analytics in social internet of things. IEEE Wireless communications, 23(5), 6874.

Ramalingam, R., Khan, S., and Mohammed, S. (2016). The need for effective information security awareness practices in Oman higher educational institutions.arXiv preprint arXiv:1602.06510.

Saxena, S., and Sharma, K. S. (2016). Integrating Big Data in "e-Oman": opportunities and challenges. info, 18(5),79-97.

Tarhini, A., Al-Badi, A., Almajali, M., and Alrabayaah, S. H. (2017). Factors Influencing Employees Intention to Use Cloud Computing. Journal of Management and Strategy, 8(2), 47-62.

Tawafak, R. M., Mohammed, M. N., Arshah, R. B. A., Shakir, M., and Mezhuyev, V. (2018). Technology enhancement learning reflection on improving Students' Satisfaction in Omani Universities. Advanced Science Letters, 24(10), 7751-7757.

Ulrich, D., and Grochowski, J. (2018). Building a world class HR department. Strategic HR Review, 17(4), 181-185. 